\title{
POU2F2 wt Allele
}

National Cancer Institute

\section{Source}

National Cancer Institute. POU2F2 wt Allele. NCI Thesaurus. Code C53112.

Human POU2F2 wild-type allele is located in the vicinity of $19 q 13.2$ and is approximately

$51 \mathrm{~kb}$ in length. This allele, which encodes POU domain, class 2, transcription factor 2

protein, plays a role in the modulation of transcription by RNA polymerase II. 